\title{
The Effect of The Quality of Service, Products \& Promotions on the Purchase Decision of Simpati Card \& It's Impact on the Satisfaction of Telkomsel Customers in Kupang City
}

\author{
Merllyn Martina ${ }^{1}$, Arifin Sitio ${ }^{2}$ \\ ${ }^{I}$ Merllyn Martina, Post Graduate Student Management, Marketing of Mercu Buana University (UMB) Jakarta, Indonesia \\ ${ }^{2}$ Arifin Sitio Post-Sarajana Marketing Management Lecturers, Mercu Buana University (UMB) Jakarta, Indonesia
}

\begin{abstract}
This study aims to examine and analyze the influence of service quality, product quality and promotion on Prepaid Card Simpati purchasing decisions and their impact on Telkomsel Customer Satisfaction in Kupang city. The type of research used is using survey research. The research method uses a descriptive survey analysis method, the sample uses probability sampling techniques with the taking technique used randomly and the total respondents are 100. The analytical method used in this study is SPSS (Statistical Package for the Social Sciences) as a tool for compiling data that has been collected to find out the purpose of the research itself. The results showed that service quality did not affect purchasing decisions, while product quality and promotion influenced the decision to purchase Simpati Telkomsel prepaid cards. While for service quality, product quality, and promotion through purchasing decisions have a positive effect on the satisfaction of Simpati Telkomsel card customers in Kupang city.
\end{abstract}

Keywords: Service Quality, Product Quality, Promotion, Purchase Decision, and Customer Satisfaction

\section{Introduction}

The needs of the Indonesian people for the performance provided by a cellphone is very high. Many factors influence this need. Starting from economic factors such as business and other needs. And the main factors that can be used in cell phone use are in terms of communication such as telephone, SMS, chat, internet, social media, and others. So that the number of mobile users reaches 371.4 million, which is greater than the population in Indonesia, which is 262 million. So far in Indonesia, four cellular operator companies control the market, namely Telkomsel, Indosat, XL, and Smartfren and Telkomsel is the market leader with the highest number of market shares. However, since the policy of Minister of Communication and Information Regulation Number 12 of 2016 concerning Telecommunications Service Customer Registration, which has been amended by Minister of Communication and Information Regulation Number 14 of 2017, the number of subscribers of operators has dropped dramatically, especially in the number of Telkomsel customers. The following is a picture of the decline in the number of customers of several operators in Indonesia:

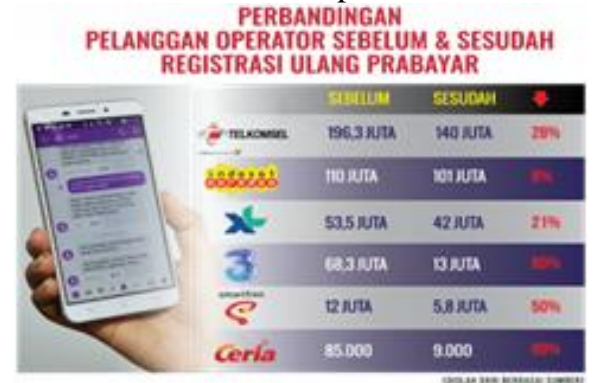

Figure1: Comparison of Operator Customers before and after prepaid re-registration.

From the picture above, it can be seen that there is a decrease in the number of Telkomsel customers reaching
56.4 million customers. The phenomenon of a decrease in the number of customers must be considered because there might be a problem that occurs. And to find out this problem must be reviewed the strategies that have been carried out.

Decreasing the number of customers can be a sign of declining satisfaction from the customers themselves. Because of the decrease in customer satisfaction, this results in a decrease in the number of customers who make purchasing decisions. In making a purchasing decision, the customer will consider several factors that exist in a product that will be purchased.

One of the factors that influence purchasing decisions is the quality of service. The definition of service quality according to Kotler and Keller (2012: 131) is the totality of features and characteristics of a product or service that depends on its ability to satisfy expressed or implied needs. Because service quality is a strategy of stimulation to customers through services provided to meet customer needs and this service can already become one in a product that is sold and also outside the product. But all that needs to be done to make customers make purchasing decisions and be satisfied. Product quality is the next factor that will influence purchasing decisions. Service features that exist in a card to be used by customer communication such as SMS, telephone, internet, MMS, video calls and several other services. Telkomsel customers are divided into Prepaid (Postpaid/Halo Card) customers and Postpaid customers (Prepaid Simpati and As card). Following are Telkomsel customer data according to the 2017 Annual Report Telkomsel: 


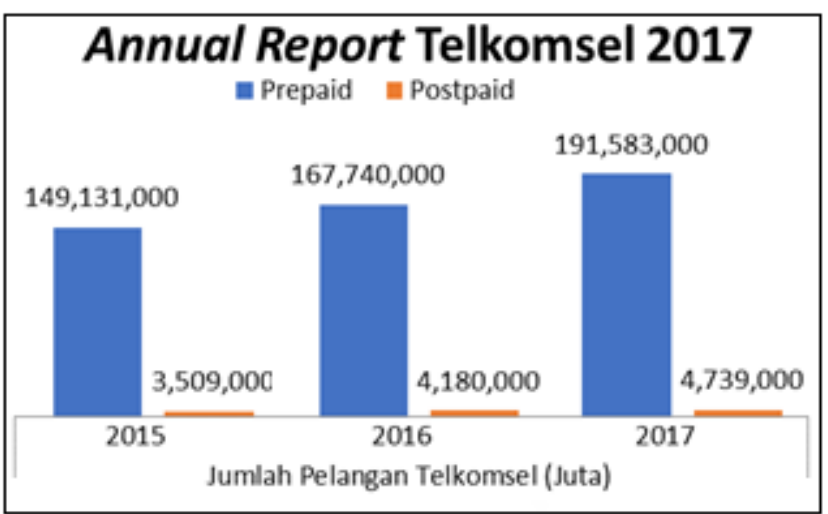

Figure 2: Graph of the number of Telkomsel customers from 2015 to 2017

The next factor that influences purchasing decisions is promotion. Promotion is a series of activities carried out to inform, to everyone and try to convince and persuade them to recognize the product and want to use and have loyalty to the product (Suryadi, 2011: 8). This promotion is one of the communications from the seller to the buyer to inform, convince, persuade, and influence the buyer to buy, acknowledge, and even royal about the product being sold.

For the case study in this study conducted on Simpati card customers in the city of Kupang, which consists of six subdistricts with a population-based on 2017 statistics, there are 412,708 inhabitants. With the number of Telkomsel customers themselves in the city of Kupang, it reaches more than $50 \%$ of the total population.

Table 1: Number of Telkomsel customers in six sub-districts

\begin{tabular}{lll}
\multicolumn{3}{c}{ in Kupang City } \\
\hline $\begin{array}{l}\text { Nama } \\
\text { Kecamatan }\end{array}$ & $\begin{array}{l}\text { Banyaknya } \\
\text { Penduduknya } \\
\text { (Juta) }\end{array}$ & $\begin{array}{l}\text { Jumlah Pelanggan } \\
\text { Simpati di Kota } \\
\text { Kupang (Juta) }\end{array}$ \\
\hline Alak & 63.389 & 32.269 \\
Mualafa & 79.581 & 40.512 \\
Oebobo & 100.149 & 50.938 \\
Kota Raja & 54.749 & 27.894 \\
Kelapa Lima & 80.26 & 40.858 \\
Kota Lama & 34.535 & 17.581 \\
Jumlah & 412.708 & 210.097 \\
\hline
\end{tabular}

From the background above, the authors made a study entitled The Effect of Service Quality, Product Quality and Promotion on Prepaid Simpati Card Purchase Decisions and Their Impact on Telkomsel Customer Satisfaction in Kupang City. This study aims to analyze the influence of service quality, product quality, and promotion on Prepaid Simpati card customer satisfaction in the city of Kupang.

\section{Theoretical Framework and Hypothesis}

\subsection{Service Quality}

According to Kotler and Keller (2012: 131) explain that service quality is a full feature and characteristic of a product or service that fits their needs to meet agreed or implied needs. This definition is a customer-centered perspective where the seller can request quality, meet demand or meet customer needs.
According to Lovelock, Wirtz, and Mussry (2013: 152-154), the focus of marketing on service quality is low quality will require companies at competitive losses. According to Tjiptono \& Chandra (2011: 115) states that the five main dimensions of service quality include:

1) Real tangibles, which contain physical facilities from, equipment or equipment used, employees and means of communication or physical representation of services provided to use these services, for example, telephone lines.

2) Reliability, namely the ability to provide promised services quickly, accurately and satisfactorily. Of the five dimensions of this factor is the most important of service quality. This determination regulates two main things, namely work consistency (performance) and reliable (reliable) capability, meaning that the company must provide its services for the first time (exactly the first time) according to the supported service schedule.

3) Responsive Power, which is the desire of staff to help customers and provide responsive service, which complements speed, competency, convenience, ease of repair, and convenience that helps the sales process for sales (ease of service).

4) Guarantees, including knowledge, ability, politeness and trustworthy abilities related to company staff, free from danger, risk or doubt, including the quality of services prepared by the customer from the product's image and solution as well as the company's liability (Quality perception).

5) Empathy includes ease in conducting relationships, good communication, attention from the company to the customer's personal and understanding the needs of customers. The higher level of competition will cause customers to face more choices of hospitality services, from price and quality. Customers will look for values that are considered high and good. Low quality will lead to customer dissatisfaction.

The research conducted by Karunia Mulya Firdaus and Rani Idawati University of Tarumanagara under the title "Effects of Service Quality, Price and Promotion on Customers' Purchase Decision of Traveloka Online" obtaining service quality results has a significant effect on purchasing decisions. And research conducted by Bayu Hadyanto Mulyo, Yoestini, Rini Nugraheni, and Mustofa Kamal 2017 with the title "Analysis of the Effect of Product Quality and Service Quality on Customer Satisfaction (Case Study of Puri Mediterranea Housing Semarang)", found to have a positive or significant influence between service quality and satisfied customer.

\subsection{Products}

According to Kotler and Armstrong (2012: 248), Products are everything that can be offered to the market to attract attention, acquisition, use, or consumption that can satisfy a desire or need. While the understanding of products according to Kotler and Keller (2012: 135) is everything that can be offered to a market to get attention, be bought, used or consumed that can satisfy desires or needs. 


\section{International Journal of Science and Research (IJSR) \\ ISSN: 2319-7064}

ResearchGate Impact Factor (2018): 0.28 | SJIF (2018): 7.426

According to Tjiptono (2010: 59), product quality is a combination of the characteristics and characteristics that determine the extent to which output can meet the requirements of customer needs or assess how far nature and characteristics meet their needs. Dimensions of product quality according to Tjiptono (2010: 61) are:

a) Performance, related to the basic operating characteristics of a product.

b) Durability, which means how long or the age of the product in question lasts before the product has to be replaced, the greater the frequency of consumer use of the product, the greater the power of the product.

c) Conformance with specifications, namely the extent to which the basic operating characteristics of a product meet certain specifications of the consumer or not found defects in the product.

d) Features are product characteristics that are designed to perfect product functions / increase consumer interest in products.

e) Reliability is the probability that the product will work satisfactorily or not in a certain period. The smaller the probability of damage, the product will be relied upon.

f) Perceived quality is often the result of using indirect measurements because there is a possibility that consumers do not understand or lack information on the product in question.

g) Serviceability, including speed and ease of repairs, as well as the competence and hospitality of its service staff.

The research conducted in 2016 with the title "The effect of brand image, product quality and price toward purchase decision found that product quality had a significant effect on purchasing decisions". And the research conducted by Bayu Hadyanto Mulyo, Yoestini, Rini Nugraheni, and Mustofa Kamal 2017 with the title "Analysis of the Effect of Product Quality and Service Quality on Customer Satisfaction (A Case Study of Puri Mediterranea Housing Semarang)" get results that have a positive or significant influence on product quality towards customer satisfaction.

\subsection{Promotion}

According to Prof. Dr. H. Buchari Alma (2013: 179) says that promotion is a type of communication that provides an explanation that convinces prospective consumers about goods and services. While according to Suryadi (2011: 8) promotion is a series of activities to communicate, give knowledge and believe people about a product, also binds the mind and the market in a form of loyalty to the product.

Rambat Lupiyoadi (2013: 178) defines that promotion is one of the variables in the marketing mix that is very important to be implemented by companies in marketing their products services. According to Subagyo (2010: 129) said that promotion is all activities intended to convey or communicate a product to the target market, to provide information about privileges, uses, and the most important thing is about its existence, to change attitudes or to encourage people to act in buy a product.

The definition of marketing communication mix from Kotler and Keller (2016: 583) is as follows: "Marketing communications mix are eight main models of communication such as advertising, sales promotion, event and experiences, and publicity public relations, online and social media marketing, mobile marketing, direct and database marketing, personal selling".

According to Prof. Dr. H. Buchari Alma (2013: 181) defines that the purpose of promotion is to provide information, attract attention and further influence the increase in sales. While the main objectives are:

1) Getting Attention,

2) Educate,

3) Remind, and

4) Convincing.

Research conducted by Teddy Chandra, Priyono \& Lukmanul Hakim in 2015 with the research title "The Influence of Location, Products, Promotions, Services for Consumer Behavior" Found that promotion had an influence on consumer behavior in making purchasing decisions. And research conducted by Jessica J. Lenzun1 James D.D. Massie Decky Adare with the title "Effect of product quality, price, and promotion on prepaid card customer satisfaction Simpati Telkomsel", Found has a positive influence between promotions on customer satisfaction.

\subsection{Purchasing Decisions}

According to Buchari Alma (2011: 96), argues that purchasing decisions are: a consumer decision that is influenced by financial economy, technology, politics, culture, product, price, location, promotion, physical evidence, people and process, thus forming an attitude on consumers to process all information and draw conclusions in the form of a response that appears what products will be purchased.

Whereas according to Kotler and Keller (2012: 167) purchasing decisions are processes where consumers pass five stages, namely problem recognition, information seeking, alternative evaluation, purchasing decisions, and post-purchase behaviour, which begins long before the actual purchase is made and has an impact long after that.

According to Novita Klarisa, purchasing decisions are the choice of two or more alternative purchasing decision choices (Klarisa, 2013: 4), it can also be interpreted that someone in making a decision must have several choices. Consumer's decision to make a product purchase includes six sub-decisions (product choice, brand choice, channel choice, time of purchase, number of purchases, payment method), Kotler and Keller which are translated A.B Susanto (2012: 184). Previous research conducted by Andhika H. Susanto 2013 entitled "The Influence of Customer Purchase Decision on Customer Satisfaction and It's Impact to Customer Loyalty". And found to have a positive influence on purchasing decisions on customer satisfaction.

\subsection{Promotion}

According to Fandy Tjiptono (2011: 146) states that satisfaction is a feeling of pleasure or disappointment someone who appears after comparing between perceptions

\section{Volume 8 Issue 7, July 2019}




\section{International Journal of Science and Research (IJSR) \\ ISSN: 2319-7064}

ResearchGate Impact Factor (2018): 0.28 | SJIF (2018): 7.426

of the performance (results) of a product with its expectations. Based on the understanding that has been explained states that satisfaction is the level of response of a person or customer to the perception of a product and service they feel.

This consumer perception is a value, if the perception is below expectations, the consumer will feel disappointed. There are several definitions according to the experts cited by Fandy Tjiptono (2011: 294) which states as follows "The consumer's fulfillment response", namely the assessment that the features of a product or service, or product / service itself, provide a level of fulfillment related to pleasant consumption, including the level of "under fulfillment" and "over fulfillment".

According to Tjiptono (2011: 295) there are several factors that influence customer satisfaction, including:

\section{a) Product quality}

Customers feel satisfied after buying and using the product and it turns out that the product used is of high quality. There are several elements of product quality, namely: performance, durability, feature, reliability, cosistency, and design.

b) Price

For sensitive customers, usually low prices are an important source of satisfaction because they will get high value for money. This price component is relatively not important for those who are not price sensitive.

c) Service quality

Customers feel satisfied when they get good or expected service. One of the most popular concepts of service quality is servqual developed by Parasuraman, Berry, and Zeithalm. Based on this concept, there are five dimensions of service quality, namely: reliability, responsiveness, assurance, empathy, and tangible.

\section{d) Emotional factor}

Customers who feel proud and confident that others are amazed when using certain brand products tend to have a higher level of satisfaction. Satisfaction is not because of product quality but pride and confidence.

e) Costs and convenience of getting a product or service. Customers will be more satisfied and happy if it is relatively easy and efficient in getting a product or service. This is because customers do not need to waste time getting products or services.

\subsection{Frameworks and Hypotheses}

The framework of researchers' thinking can be illustrated with the following picture

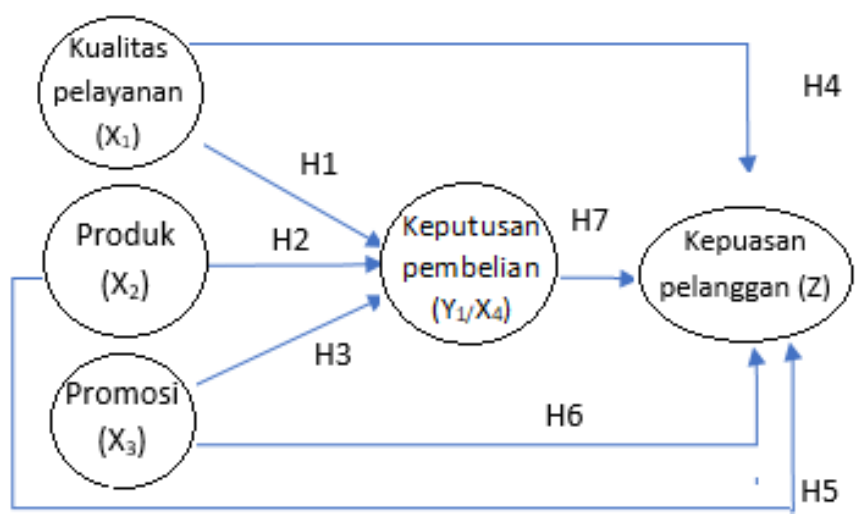

Figure 3: Mind Map

The hypothesis made by researchers based on the framework is as follows:

H1: It is assumed that service quality has a positive and significant effect on the decision to purchase Prepaid Simpati card products in the city of Kupang.

H2: It is assumed that Product Quality has a positive and significant effect on the decision to purchase Prepaid Simpati card products in the city of Kupang.

H3: Allegedly promotion has a positive and significant effect on purchasing decisions for Prepaid Simpati card products in the city of Kupang.

H4: It is assumed that service quality has a positive and significant effect on the satisfaction of Prepaid Simpati card customers in Kupang city.

H5: It is suspected that product quality (Product Quality) has a positive and significant effect on the satisfaction of Prepaid Simpati card customers in Kupang city.

H6: Allegedly promotion (Promotion) has a direct positive effect on the satisfaction of Prepaid Simpati card customers in the city of Kupang.

H7: Alleged Decision on Prepaid Simpati card purchases has a positive and significant effect on customer satisfaction in the city of Kupang.

\section{Research Methods}

The type of research used by the author is to use survey research. According to Sugiyono (2015: 11), the survey is: "Research conducted using questionnaires as a research tool carried out in large and small populations, but the data studied is data from samples taken from the population, so that relative events, distribution, and relationships between variables, sociological and psychological ".

The research method uses descriptive survey analysis methods. The descriptive survey analysis method is a survey method to explain and describe the relationship of independent variables to the dependent variable. In this study, the researchers wanted to find out how much influence the quality of service, products, and promotions on the decision to purchase Simpati prepaid cards and their impact on the satisfaction of Telkomsel customers in the city of Kupang.

The data used are primary data. And in sampling, the researchers used probability sampling methods using simple random sampling where the samples used were taken ran- 


\section{International Journal of Science and Research (IJSR) \\ ISSN: 2319-7064}

ResearchGate Impact Factor (2018): 0.28 | SJIF (2018): 7.426

domly. The number of samples to be used is 100 samples. The measuring technique used by researchers is the Likert scale. Likert scale is used to measure the attitudes, opinions, and perceptions of a person or group of people about social phenomena (Sugiono, 2015: 93). It uses a Likert scale. And the tool used for researchers to compile and process data is SPSS 22. In this case, the population that became the object of the study was the citizens of Kupang (consumers) who used the Simpati Telkomsel prepaid card. To calculate the determination of the number of samples from a particular population developed, Slovin formula is used. Then the number of samples taken using the Slovin formula is as follows:

$$
n=\frac{N}{1-N e^{2}}
$$

Next is the population in Kupang city based on data from the 2017 Statistics and Telkomsel Agency:

Table 2: Number of Telkomsel customers in six sub-districts in Kupang City

\begin{tabular}{lll}
\hline $\begin{array}{l}\text { Nama } \\
\text { Kecamatan }\end{array}$ & $\begin{array}{l}\text { Banyaknya } \\
\text { Penduduknya } \\
\text { (Juta) }\end{array}$ & $\begin{array}{l}\text { Jumlah Pelanggan } \\
\text { Simpati di Kota } \\
\text { Kupang (Juta) }\end{array}$ \\
\hline Alak & 63.389 & 32.269 \\
Mualafa & 79.581 & 40.512 \\
Oebobo & 100.149 & 50.938 \\
Kota Raja & 54.749 & 27.894 \\
Kelapa Lima & 80.26 & 40.858 \\
Kota Lama & 34.535 & 17.581 \\
Jumlah & 412.708 & 210.097 \\
\hline
\end{tabular}

The variables used in the study can be classified into:

A. Independent variable, which is a variable that explains in influencing other variables. So in this study thein dependent variables are:

1) Service Quality (X1)

Service quality is any form of activity that is interpreted as a service or service delivered by the owner to the customer in the form of convenience, speed, relationship, ability and hospitality aimed at attitudes and characteristics in providing services for customer satisfaction. The dimensions used in service quality variables are tangibles, empathy, responsiveness, assurance, and reliability.

2) Product Quality (X2)

The quality of a product through several stages of the process by taking into account the value of a product, in which there are product capabilities, product suitability, product reliability, and even other additional features full of innovations. The dimensions used in product quality variables are performance, feature, and conformance.

\section{3) Promotion (X3)}

Promotion is a way that is done to attract the attention of customers by informing, persuading, and assure prospective customers and old customers of the products we create to make requests or purchases of these products and make consumers loyal to these products.
The dimensions used in promotion variables are advertising, event and experience, and sales promotion.

B. Dependent or bound variables, namely variables explained and influenced by independent variables. The dependent variable is often called the output variable, criteria, and consequent or dependent variable. This variable is a variable that is influenced or becomes a result, because of the existence of independent variables. So in this study, the dependent variable is:

\section{1) Purchasing Decision (Y)}

The purchase decision is a process that begins with the introduction of the problem of what products are needed, then searches for information about the product, evaluates the product from the superiority of the product and benefits of the product, then buys the most useful products. The dimensions to be examined in the Purchase Decision variable are the best choices, product character, product brand image, choice of brands, and explorative interests.

\section{2) Customer Satisfaction $(Z)$}

Customer satisfaction is a feeling of pleasure or customer disappointment that arises after comparing the perceptions of the performance (results) of a product with its expectations. The dimensions used by researchers for variable customer satisfaction are service quality, product quality, and emotional factors.

\section{Research and Discussion Results}

Based on the results of research and data processing using SPSS 22 test equipment with several 100 respondents and using the basis for data validity, it can be said to be valid, ie if the results of $\mathrm{r}$ table are greater than 0.1996 and for reliability 0.7 . Then from the test results, the following results are obtained:

1) Service quality variable (X1) is valid and realistic

2)Product quality variable (X2) is valid and realistic

3)Promotional variables (X3) are valid and realistic

4) Variable purchasing decisions (X4) are valid and realistic

5)Customer satisfaction variable (X5) is valid and realistic

Likewise, the Normality Test is conducted to find out whether the data in the regression equation are normally distributed or abnormally distributed. Normality test is needed to find out whether the independent variable with the dependent variable distribution is normal or near normal. How to test residual normality by using the histogram graph and p-plot of the SPSS version 22 program.

The basis for decision making on this normality test is as follows:

a) If the significant number of the Kolmogorov-Smirnov test sig $\geq 0.05$ the data is normally distributed.

b) If the significant number of the Kolmogorov-Smirnov test $\operatorname{sig} \leq 0.05$ the data is abnormally distributed.

Based on the test results for the normality test, the data in the study were normally distributed.

\section{Volume 8 Issue 7, July 2019 www.ijsr.net}




\section{International Journal of Science and Research (IJSR) \\ ISSN: 2319-7064}

ResearchGate Impact Factor (2018): 0.28 | SJIF (2018): 7.426

Homogeneity tests are used to show that two or more groups of sample data come from populations that have the same variation. Homogeneity test is applied to the post-test data from the experimental group and the control group. To measure the homogeneity of the variance of the two groups of data, use the $\mathrm{F}$ test formula as follows:

\section{$F=$ Largest variant \\ Smallest variant}

The significance level used is $\alpha=0.05$. The homogeneity test uses SPSS with the criteria used to conclude if the F count is greater than $\mathrm{F}$ table, then it has a homogeneous variant. However, if $\mathrm{F}$ count is smaller than $\mathrm{F}$ table, the variance is not homogeneous.

Based on the results of testing in this research, including homogeneous categories.

The variables used in the study can be classified into:

a) Independent variable, which is a variable that explains in influencing other variables. So in this study thein dependent variables are:

1) Service Quality (X1)

Service quality is any form of activity that is interpreted as a service or service delivered by the owner to the customer in the form of convenience, speed, relationship, ability and hospitality aimed at attitudes and characteristics in providing services for customer satisfaction. The dimensions used in service quality variables are tangibles, empathy, responsiveness, assurance, and reliability.

2) Product Quality (X2)

The quality of a product through several stages of the process by taking into account the value of a product, in which there are product capabilities, product suitability, product reliability, and even other additional features full of innovations. The dimensions used in product quality variables are performance, feature, and conformance.

3) Promotion (X3)

Promotion is a way that is done to attract the attention of customers by informing, persuading, and assure prospective customers and old customers of the products we create to make requests or purchases of these products and make consumers loyal to these products. The dimensions used in promotion variables are advertising, event and experience, and sales promotion.

b) Dependent or bound variables, namely variables explained and influenced by independent variables. The dependent variable is often called the output variable, criteria, and consequent or dependent variable. This variable is a variable that is influenced or becomes a result, because of the existence of independent variables. So in this study, the dependent variable is:

1) Purchasing Decision (Y)

The purchase decision is a process that begins with the introduction of the problem of what products are needed, then searches for information about the product, evaluates the product from the superiority of the product and benefits of the product, then buys the most useful products. The dimensions to be examined in the Purchase Decision variable are the best choices, product character, product brand image, choice of brands, and explorative interests.

2) Customer Satisfaction (Z)

Customer satisfaction is a feeling of pleasure or customer disappointment that arises after comparing the perceptions of the performance (results) of a product with its expectations. The dimensions used by researchers for variable customer satisfaction are service quality, product quality, and emotional factors.

\subsection{Hypothesis Testing}

\section{A.Path Model 1 Test Results}

The results of testing the variables of service quality, product quality, and promotion of customer satisfaction in the following table:

Table 3: Effect of Independent Variables (X1, X2, X3) Partially Against Dependent Variables (Y) Coefficients $^{\mathrm{a}}$

\begin{tabular}{lcllll}
\hline Model & \multirow{2}{*}{ B } & $\begin{array}{l}\text { Unstandardized } \\
\text { Coeffecients } \\
\text { Std. Error }\end{array}$ & $\begin{array}{l}\text { Standardized } \\
\text { Coeffecients } \\
\text { Beta }\end{array}$ & T & Sig \\
\hline (Constant) & 3.323 & 1.590 & & 2.090 & .039 \\
Service Quality & .020 & .037 & .062 & .545 & .587 \\
Product & .109 & .040 & .346 & 2.753 & .007 \\
Promotion & .808 & .167 & .435 & 4.826 & .000 \\
\hline
\end{tabular}

Based on the table above, hypotheses and structural equations can be formulated as follows:

$\mathrm{Y}=\rho \mathrm{yx} 1 \mathrm{X} 1+\rho 2 \mathrm{yx} 2 \mathrm{X} 2+\rho \mathrm{yx} 3 \mathrm{X} 3+\varepsilon \mathrm{i}$

$\mathrm{Y}=0.062 \mathrm{X} 1+0.346 \mathrm{X} 2+0.435 \mathrm{X} 3+0.644$

Following is the model 1 diagram path diagram

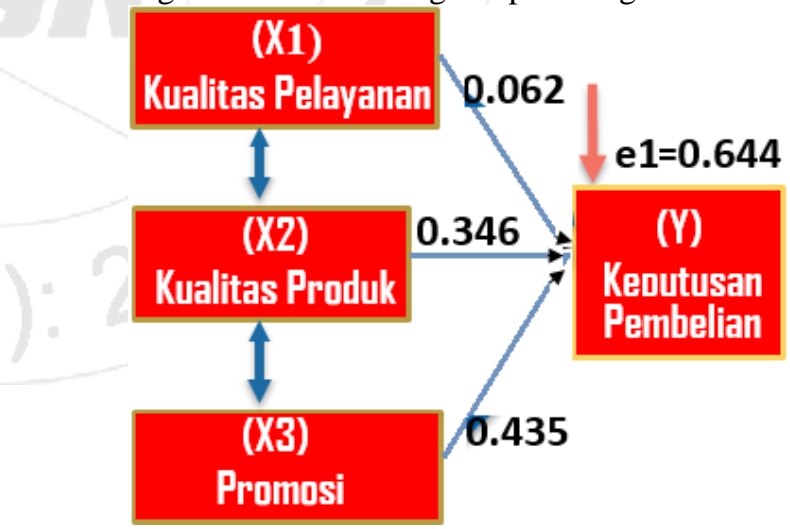

Figure 4: Path Diagram Model 1

1) Based on the results of hypothesis testing, there is no effect on the quality of service on purchasing decisions. From the results of the statistical $t$ value for service quality on purchasing decisions of $0.545<1.985$ ( $\mathrm{t}$ table). This explains that the quality of service provided by Telkomsel to Simpati card customers in Kupang city is not good or is still insufficient which causes customers not to make purchasing decisions because of the quality of services provided. The results of this study also contradict the previous research conducted by "Carunia Mulya Firdausy and Rani Idawati University of Tarumanagara under the title Effects of Service Quality, 


\section{International Journal of Science and Research (IJSR) \\ ISSN: 2319-7064}

ResearchGate Impact Factor (2018): 0.28 | SJIF (2018): 7.426

Price and Promotion on Customers' Purchase decision of Traveloka Online". The result is that service quality has a significant effect on purchasing decisions.

2) Based on the results of hypothesis testing, there is a significant effect on product quality on purchasing decisions. Based on the results of $t$ statistics for product quality against purchasing decisions of 2.753> 1985 (t table). This explains that the quality of the products provided by Telkomsel, namely the Simpati card, has conformity to what is needed by Telkomsel customers in the city of Kupang. Means that the better the quality of the product in meeting customer needs, the higher the level of purchase of the product. Telkomsel's strategy for product quality in the form of a Simpati starter card in the city of Kupang can be said to be successful.

3) Product quality has a significant influence on purchasing decisions because of the many official outlets that sell Simpati prime card products making it easier for customers to reach them. And the available network, 4G in Kupang city is still quite good. This is in line with previous research conducted in 2016 with the title The effect of brand image, product quality and price toward a purchase decision to get results that product quality has a significant effect on purchasing decisions.

4) Based on the results of hypothesis testing, there is a significant influence between promotions on purchasing decisions. With the results of the t-test value for the promotion of purchasing decisions amounting to 4,826> 1,985 (t table). This explains that the promotion strategy carried out by Telkomsel on prepaid Simpati cards succeeded and made customers in Kupang city make purchasing decisions. The more frequent promotions carried out by Telkomsel on prepaid Simpati cards the greater the purchasing decisions that will occur by the customer.

This is in line with previous research conducted by "Teddy Chandra, Priyono \& Lukmanul Hakim in 2015 with the research title The Influence of Location, Products, Promotions, Services concerning Consumer Behavior." And the results showed that the promotion influenced consumer behaviour. in making purchasing decisions.

\section{B.Path Model 2 Analysis Test Results}

The results of testing the variables of service quality, product quality, promotion and purchasing decisions on customer satisfaction are the following table:

Table 4: Effect of Independent Variabels (X1, X2, X3) \& (Y/X4) Partially Against Dependent Variables (Z)

\begin{tabular}{|c|c|c|c|c|}
\hline Model & $\begin{array}{l}\text { Unstandardized } \\
\text { Coeffecients } \\
\text { Std. Error }\end{array}$ & $\begin{array}{l}\text { Standardized } \\
\text { Coeffecients } \\
\text { Beta }\end{array}$ & $\mathrm{T}$ & Sig \\
\hline (Constant) & .984 & & 5.483 & .000 \\
\hline Service Quality & .022 & .149 & 2.072 & .041 \\
\hline Product & .025 & .122 & 1.997 & .049 \\
\hline Promotion & .113 & .103 & 1.623 & .108 \\
\hline $\begin{array}{l}\text { Purchasing } \\
\text { Decision }\end{array}$ & .062 & .744 & $\begin{array}{l}11.60 \\
5\end{array}$ & .000 \\
\hline
\end{tabular}

Based on the table above, hypotheses and structural equations can be formulated as follows:

$\mathrm{Z}=\rho \mathrm{zX} 1 \mathrm{X} 1+\rho \mathrm{zx} 2 \mathrm{X} 2+\rho \mathrm{zx} 3 \mathrm{X} 3+\rho \mathrm{zX} 4 \mathrm{X} 4+\varepsilon 2$

$\mathrm{Z}=0.149 \mathrm{X} 1-0.005 \mathrm{X} 2+0.103 \mathrm{X} 3+0.744 \mathrm{X} 4+0.402$

Here's a picture of model 2 path diagram

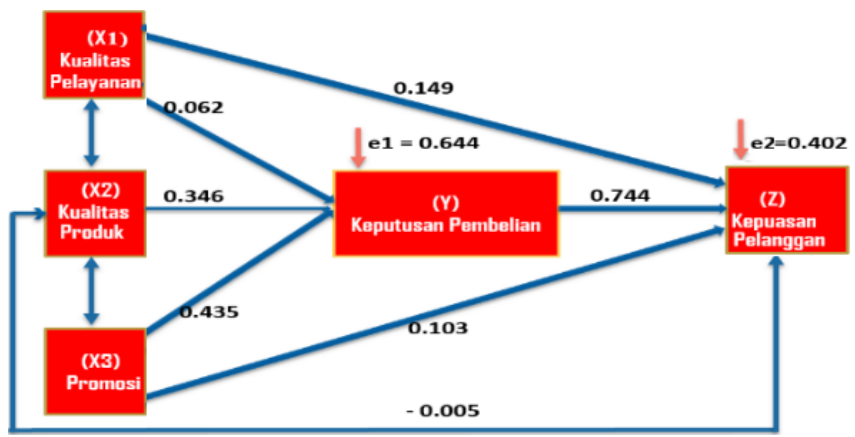

Figure 5: Path Diagram Model 2

1) The results of the study prove that service quality has a significant direct effect on customer satisfaction. With the results of the t-test value for service quality on customer satisfaction by 2.072>1.985 ( $\mathrm{t}$ table). These results indicate the increasing quality of services provided by Telkomsel on sympathetic prepaid products, customer satisfaction will also increase. This is in line with previous research conducted by "Teddy Chandra, Priyono \& Lukmanul Hakim in 2015 with the research title The Influence of Location, Products, Promotions, Services concerning Consumer Behavior." And the results show that service quality has an influence on behaviour consumers in making customer satisfaction.

2) The results of the above research show that product quality affects customer satisfaction. With the results of the t-test, the quality of the product for customer satisfaction is 1997> 1985 ( $\mathrm{t}$ table). This proves that the better the quality of the products provided, the more customer satisfaction will be increased. This is in line with previous research by Bayu Hadyanto Mulyo, Yoestini, Rini Nugraheni, and Mustofa Kamal 2017 with the title Analysis of the Effect of Product Quality and Service Quality on Customer Satisfaction (A Case Study of Puri Mediterranea Housing in Semarang. product to customer satisfaction.

3) Based on the results of hypothesis testing, there is no effect on customer satisfaction. With the results of the promotion t-test on customer satisfaction amounting to $1,623<1,985$ ( $\mathrm{t}$ table). These results indicate that the quality of the product does not affect the satisfaction of prepaid Simpati customer cards in the city of Kupang. This is not in line with previous research conducted by Jessica J. Lenzun1 James D.D. Massie2 Decky Adare with the title Effect of product quality, price and promotion on prepaid card customer satisfaction Simpati Telkomsel. And found to have a positive influence between promotions on customer satisfaction.

4) Based on the results of testing the hypothesis testing there is a significant effect of purchasing decisions on customer satisfaction. with the results of the t-test the purchase decision on customer satisfaction amounted to 11.605> 1985 ( $\mathrm{t}$ table). This shows that the more buying decisions, 


\section{International Journal of Science and Research (IJSR) \\ ISSN: 2319-7064}

ResearchGate Impact Factor (2018): 0.28 | SJIF (2018): 7.426

the more customer satisfaction increases. Because customer satisfaction will not occur without a purchase decision first. Where this happens because of the level of satisfaction of the product so that the customer decides to make a purchase.

This is in line with previous research conducted by Andhika H. Susanto 2013 under the title The Influence of Customer Purchase Decision On Customer Satisfaction And It 's Impact To Customer Loyalty. And found to have a positive influence between purchasing decisions on customer satisfaction

\section{C.Line Model 1 and 2 Test Results}

The following are the results of the analysis of direct and indirect effects based on the model 1 and 2 paths as in the table below:

Table 5: Calculation of Direct, Indirect Effects \& Total Influence

\begin{tabular}{llrll}
\hline No & Variable & Direct & Indirect & Total \\
\hline 1 & $\mathrm{X}_{1} \mathrm{Y}$ & 0.062 & & \\
2 & $\mathrm{X}_{1} \mathrm{Z}$ & 0,149 & 0.046 & 0,195 \\
3 & $\mathrm{X}_{2} \mathrm{Y}$ & 0.346 & 0.257 & 0,379 \\
4 & $\mathrm{X}_{2} \mathrm{Z}$ & 0,122 & & \\
5 & $\mathrm{X}_{3} \mathrm{Y}$ & 0.435 & & \\
6 & $\mathrm{X}_{3} \mathrm{Z}$ & 0.103 & 0.323 & 0.426 \\
7 & $\mathrm{YZ}$ & 0.744 & & \\
\hline
\end{tabular}

1) Based on the results of the calculation above Regarding the direct value of 0.149 and the indirect effect of 0.046 which means that the direct value is greater than the large indirect value, this result shows that $\mathrm{X} 1$ directly has significant significance for Z. "This is Teddy Chandra, Priyono \& Lukmanul Hakim" in 2015 with the research title Effect of Location, Products, Promotions, Services with a Sense of Consumer Behavior. consumers in making customer satisfaction.

2) Based on the results of the calculation above. It is estimated at 0.122 and indirect effect of 0.257 which means that the value is indirectly greater than the direct value, this result indicates this indirectly X2. This contradicts the research conducted by Setiawan Tri Saputra, Kadarisman Hidayat, and Sunarti in 2017 with the research title on improving the Quality of Products Against Purchasing Decisions and Their Impact on Customer Satisfaction of iPhone Users. And the results obtained directly result in greater product quality towards consumer satisfaction with indirect through purchasing decisions.

3) Based on the results of the calculation above. It is estimated at 0.103 and indirect effects of 0.324 which means indirect values are greater than those associated with direct values, this result shows that indirectly X3 through Y corresponds to the significance of Z. Faith Heryanto in 2015 with the research title Analysis of the Effect of Products, Prices, Distribution and Promotion on Purchasing Decisions and Their Impact on Customer Satisfaction. and direct promotion of customer satisfaction is obtained through greater purchase decisions and more about the direct promotion of customer satisfaction.

\section{Conclusion}

Based on the results of the research and discussion in the previous chapter, it can be concluded that the influence of service quality, product quality, and promotion on prepaid card purchase Simpati decisions and their impact on Telkomsel customer satisfaction in Kupang city as follows:

1) The quality of Telkomsel services in the city of Kupang partially does not significantly influence the decision to purchase Telkomsel sympathetic prepaid cards in the city of Kupang. This is because Telkomsel still cannot satisfy or is not good at serving its customers.

2) There is a positive and significant influence between product qualities on the decision to purchase Telkomsel sympathetic prepaid cards in Kupang, which means that the better the quality of the product in meeting customer needs, the higher the level of purchase of the product.

3) There is a positive and significant influence between the promotions of the decision to purchase Telkomsel sympathetic prepaid cards in the city of Kupang. Where the more frequent promotions carried out by Telkomsel on prepaid Simpati cards the greater the purchasing decisions that will occur by the customer. By doing a sales promotion by giving a bonus in the form of SMS, telephone, internet quota, things like this will have a significant influence on the decision to purchase the Simpati Telkomsel prepaid card.

4) Partial service quality has a positive and significant effect on customer satisfaction. This explains that service quality with indicators consisting of service officers responding to customer complaints, the ability of knowledge of service personnel, the appearance of service personnel, convenient facilities and accuracy of the information that guarantees that service officers have a positive and significant influence on customer satisfaction. This means that this condition proves that the better services provided by service personnel can increase customer satisfaction.

5) Partial product quality has a positive and significant effect on customer satisfaction. This explains that the quality of the product is still unsatisfactory for prepaid card subscribers, the Simpati of the Kupang people.

6) Promotion there is no significant influence on customer satisfaction. because the promotion carried out is still less intense so that the satisfaction of the prepaid card Simpati customers is less able.

7) There is a positive and significant influence between purchasing decisions on the satisfaction of Telkomsel sympathetic prepaid card customers in Kupang, this is because the Simpati customers in Kupang are satisfied with the product and choose to purchase a Simpati card. The main factor that is the determinant is because of similar competitors in this case other providers such as Indosat and XL, have not been able to compete with Telkomsel products, in terms of network quality and which tower number, Telkomsel is the only provider that has the widest range to all corners remote in the Indonesian homeland.

\section{Volume 8 Issue 7, July 2019 www.ijsr.net}




\section{International Journal of Science and Research (IJSR) \\ ISSN: 2319-7064}

ResearchGate Impact Factor (2018): 0.28 | SJIF (2018): 7.426

This study has limitations, whether previously known or unexpected. As for some limitations and suggestions for further research, the number of respondents is only 100, so the data obtained have not yet described the conditions that are very definite in the case of customer satisfaction of prime card Simpati and the factors that influence it in the city of Kupang. For further research, it can be done with a greater number of respondents so that the results of the study are more satisfying than what the researchers have done.

\subsection{Suggestions}

Suggestions given by researchers to Telkomsel companies on Simpati prepaid cards in Kupang city are as follows:

1) The quality of Telkomsel services in the city of Kupang needs to be improved especially on Simpati cards, still feeling the slow service provided by Grapari Telkomsel to customers in the city of Kupang, This should get more attention because the quality of service is the spearhead of the success of a business. Because currently competing providers such as Indosat, XL continues to increase the quality of its service to get as many customers as possible. Therefore Telkomsel must be committed to continuously striving to build its image well through improving service performance to achieve excellent performance services, where customer satisfaction and customer loyalty are the central focus. The company's commitment to always provide superior service is expected to minimize customer dissatisfaction.

2) Based on the results of the analysis on research, obtained extensive network signal quality, ease of finding a place outlet for credit purchases, authenticity (product originality), famous and trusted brands, features/facilities and ease of use of card instructions can be satisfying. However, there are still customer complaints related to the quality of the $4 \mathrm{G}$ network that is still often encountered obstacles, which often cannot be used. Besides, another factor that is also an important concern for Telkomsel is competing providers such as Indosat and $\mathrm{XL}$ will continue to improve the quality of their products, especially in some segments such as novice users or customers who want to get cellular products with good quality and at low prices. Therefore Telkomsel must continue to improve the quality of Simpati products in the city of Kupang.

3) It is recommended to the management of PT Telkomsel, especially in the city of Kupang, to keep doing attractive and effective promotional strategies because these variables are proven to be able to make purchasing decisions and can increase customer satisfaction. By giving bonus SMS, telephone, internet quota, and others.

4) To improve the purchase decision of the Telkomsel Simpati card, especially so that customers do not move to other providers, it can be done by giving new and attractive offers to Telkomsel loyal customers, such as providing bonuses for customers who have subscribed for more than five years. and to increase the loyalty of Grapari Telkomsel customers in Kupang city.

The place has a significant effect on customer satisfaction. This indicates that the Grapari office that is getting better and more comfortable will increase customer satisfaction.
Therefore, it is better for PT Telkomsel to continue to improve the quality and comfort of Grapari and to add the latest and better services in Grapari because these variables are proven to increase customer satisfaction.

\section{References}

[1] Kotler, Keller. 2012. Marketing Management (Edisi 14). Pearson : England

[2] Suryadi, Didih. 2011. Promosi Efektif Menggugah Minat \& Loyalitas Pelanggan. Jakarta: PT. Gramedia

[3] Lovelock, Christopher, Jochen Wirtz, \& Jacky Mussry. 2011. Pemasaran Jasa. edisi 7. Erlangga: Jakarta.

[4] Tjiptono, Fandy dan Gregorius Chandra. 2011. Service, Quality and Satisfaction. Yogyakarta: Andi.

[5] Kotler, Philip. \& Gary Armstrong. 2012. Principle Of Marketing, 15 th edition. New. Jersey: Pearson Prentice Hall.

[6] Tjiptono, Fandy. 2010. Strategi Pemasaran, Edisi 2. Yogyakarta: Andi.

[7] Alma, Buchari. 2013. Manajemen Pemasaran dan Pemasaran Jasa. Bandung: Alfabeta.

[8] Suryadi, Didih. 2011. Promosi Efektif Menggugah Minat \& Loyalitas Pelanggan. Jakarta: PT. Gramedia

[9] Lupiyoadi, Rambat. 2013. Manajemen Pemasaran jasa, Jakarta: Salemba Empat.

[10]Ahmad, Subagyo. 2010. Marketing In Business. edisi pertama, cetakan pertama.Jakarta: Mitra Wacana Media.

[11]Klarisa, Novita. 2013. Pengaruh Bauran Promosi Terhadap Keputusan Pembelian Konsumen Pada Swalayan Maxi Balikpapan. Balikpapan.

[12]Sugiyono. 2015. Metode Penelitian Pendidikan (Pendekatan Kuantitatif, Kualitatif dan R\&D). Penerbit CV. Alfabeta: Bandung.

[13]Bayu Hadyanto Mulyono, Yoestini , Rini Nugraheni, Mustofa Kamal. 2017,. "Analisis Pengaruh Kualitas Produk Dan Kualitas Layanan Terhadap Kepuasan Konsumen (Studi Kasus Pada Perumahan Puri Mediterania Semarang)", Jurnal Studi Manajemen \& Organisasi Volume 4, nomor 2, Juli.

[14]Chandra, Teddy Et Al. 2015, The Influence of Location, Products, Promotions, Services with Respect to Consumer Behavior. Canadian Center of Science and Education : Vol. 7, No. 12.

[15]Susanto, Andhika H. 2013, The Influence Of Customer Purchase Decision On Customer Satisfaction And It's Impact To Customer Loyalty. Jurnal EMBA : Vol 1, no.1.

[16]Jessica J. Lenzun, James D.D. Massie dan Decky Adare. 2014. Pengaruh Kualitas Produk, Harga dan Promosi Terhadap Kepuasan Pelanggan Kartu Prabayar Telkomsel, Jurnal EMBA Vol.2 No 3 Hal. 1237-1245.

[17]Heryanto, Imam. 2015. Analisa Pengaruh Produk, Harga, Distribusi Dan Promosi Terhadap Keputusan Pembelian Serta Impilkasinya Terhadap Kepuasan Pelanggan. Jurnal Ekonomi, Bisnis dan Enterprineurship Vol. 9 no. 2 hal 80-101.

[18]Saputra, Setiawan Tri Et Al. 2017. Pengaruh kualitas produk terhadap keputusan pembelian dan dampaknya terhadap kepuasan konsumen pengguna Iphone. Jurnal Administrasi Bisnis (JAB) Vol.5 No.6 Hal.85-95.

\section{Volume 8 Issue 7, July 2019}

